\title{
焼却灰の処理技術・利用技術
}

\author{
$\mathrm{JFE}$ 環境ソリューションズ株式会社 環境設計部 明 石 哲 夫
}

\section{Ash Treatment Technology and Reuse Technology by Ash Melting System}

Testuo Akashi

Environmental \& Recycling Plant Engineering \& Design Dept., JFE Environmental Solutions Corporation

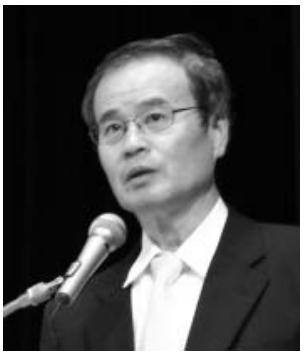

講演者：横山 隆

This paper explained ash treatment technology and reuse technology which are developed in the MSW [municipal solid waste] incineration process. Next, new melting process of MSW incinerator ash was introduced, and then new reuse technology of slag produced by MSW-melting process was introduced.

Keywords : Ash, Melting Process, Slag, Reuse, Municipal Solid Waste

分類 $: \mathrm{X}_{1}$ 環境総論, $\mathrm{X}_{7}$ 産業廃棄物

\section{1. はじめに}

一般廃棄物の焼却後の灰は，おもに最終処分場に埋め立 て処理されている。平成 16 年度で国内の一般廃棄物 5,059 万トンの $77.5 \%$ が 1,374 施設で焼却処理されて, その中 間処理後の埋立て量は 632 万 $\mathrm{t}$ に達している。最終処分場 は全国 2,009 ケ所あるが, 新規の確保は難しくなっており 減少傾向で, その残容量も厳しい状況にある。また, 自都 道府県外の施設に最終処分を目的として搬出された一般廃 裹物は 48.3 万トンである。このように, 燒却残渣の減容 化が各自治体のごみ行政の大きな課題となっている。

焼却残渣（焼却灰とばいじん）には鉛やカドミウム，六 価クロムなどの有害重金属が微量含まれるため, これらの 有害重金属の地下水への溶出が起こらないように安定化処 理する必要がある。特に, 焼却施設の排ガスから集塵され るばいじん（飛灰）には重金属が多く含まれるため特別管 理一般廃裹物として指定され, 法で定められた方法（後述 2 項を参照）によって安定化処理を行なわなければならな w。

また，ダイオキシン類対策特別措置法の制定により，重 金属の溶出の観点に加え, ダイオキシン類の無害化の観点 で灰処理方法が見直されている。焼却灰についても規制值 以上のダイオキシン類が含まれると, 飛灰と同様に特別管 理一般廃裹物として扱われるようになった。

飛灰安定化処理は, 以前はセメント固化が中心であった
が，埋め立て基準の溶出規制值の強化に伴い，薬剤処理や その併用が中心となった。さらに，ダイオキシン類の無害 化のため溶融処理や焼成（セメント原料化）等の加熱処理 が広く採用されるようになってきた。

また，溶融処理やセメント原料化では，ダイオキシン類 と重金属が同時に処理でき，処理物が有効利用可能な方法 であることから，最終処分問題を解決する焼却残渣処理の 最も有効な手段として, 近年急速に普及拡大している。 （2004 年度末で 143 施設が稼動：民間施設 5 を含む）また, 焼却灰の溶融処理を行う場合には, 焼却灰と飛灰を同時溶 融する混合溶融処理が一般化している。

さらに, 焼却から溶融までの処理を, 廃棄物から直接溶 融処理するプロセス（ガス化溶融炉，ガス化改質炉）が開 発され, 近年広く導入され, 稼働施設も急増してきた。

また，処理後のスラグやセメントを再資源化物として有 効利用し, 最終処分場量を最小化することが望まれること から, 溶融スラグやエコセメントの標準化（JIS 化）が進 められている。また, 溶融処理で分離される溶融メ夕ルを 銅精錬の原料などに利用する再資源化技術や，溶融炉排ガ スから集塵される溶融飛灰中に含まれる亜鉛や鉛などの重 金属を非鉄精錬の原料化する山元還元技術が検討され実用 化段階にある。

\section{2. 法で定められたばいじんの処理方法}

平成 3 年 10 月に「廃棄物処理法」が改正され，ごみ焼 
表 1 法で定められた「ばいじん」の処理方法

\begin{tabular}{l|l}
\hline & \multicolumn{1}{|c}{ 処理方法 } \\
\hline (1) & 溶融固化による安定化 \\
\hline (2) & セメント固化による安定化 \\
\hline (3) & 薬剤処理による安定化 \\
\hline (4) & 酸その他の溶媒による重金属の抽出による安定化 \\
\hline (5) & 焼成処理による安定化 \\
\hline
\end{tabular}

表 2 廃棄物の埋め立て基準

\begin{tabular}{l|l}
\hline \multicolumn{1}{c|}{ 項目 } & \multicolumn{1}{c}{ 溶出基準 } \\
\hline カドミウム & $0.3 \mathrm{mg} / 1$ 以下 \\
\hline 鉛 & $0.3 \mathrm{mg} / 1$ 以下 \\
\hline 六価クロム & $1.5 \mathrm{mg} / 1$ 以下 \\
\hline ひ素 & $0.3 \mathrm{mg} / 1$ 以下 \\
\hline 総水銀 & $0.005 \mathrm{mg} / 1$ 以下 \\
\hline セレン & $0.3 \mathrm{mg} / 1$ 以下 \\
\hline
\end{tabular}

却処理施設から発生するばいじん（飛灰）が「特別管理一 般廃棄物」として指定され，厚生省告示第 194 号（平成 4 年 7 月 3 日）でばいじんの処理方法が以下の 4 通りに定め られた。

その後, 平成 12 年 1 月にダイオキシン類対策特別措置 法の制定に伴い，上述のように廃衰物焼却炬に係わるばい じんと焼却灰はダイオキシン類の処理基準は同じ法規制が かかるようになり, 同時に特別管理一般廃棄物の処理法と して，5番目の処理としてのエコセメントを含む焼成処理 が追加された（表 1）。

また，安定化処理した処理物は表 2 に示す廃棄物埋め立 て基準を満たす必要がある。

\section{3. 処理技術}

\section{1 溶融処理}

灰の溶融固化法とは, 油等の燃料または電気のエネルギ 一を利用して，灰を $1,200^{\circ} \mathrm{C}$ 以上の高温に処理することに より, 有機物を燃焼・ガス化し, 有害重金属は無機塩類と ともに溶融飛灰として揮発分離させ, 主要成分の無機物は ガラス状の溶融スラグとする方法である。

溶融炉形式によって溶融温度や溶融雲囲気 (酸化・還元) 等の違いによって溶融処理による元素の移行挙動（スラグ, メタル，溶融飛灰への移行割合）は影響を受けるが，溶融 処理温度域では揮散しやすい重金属類の大半は溶融飛灰や 溶融メ夕ルに移行するため, 無機質が溶融固化するスラグ には有害重金属類は微量となる。スラグ中にわずかに残る 重金属も，非晶質のガラス網目構造の中に封じ込められる ため安定化する。

排ガス中に揮散した灰中の重金属類は，溶融排ガスの冷 却に伴い再び固体となり，ダスト化して排ガス集鹿装置で
溶融飛灰として捕集される。溶融飛灰は，特別管理一般廃 棄物（ばいじん）の安定化処理方法における溶融以外の方 法で処理しなければならない。

この溶融飛灰中には亜鉛や鉛などの有価な金属類が多く 含んでいるため, 電炉ダストのリサイクルと同様の技術を 適用して，無機塩類を水洗いして脱塩処理し，有価金属の 抽出や濃縮プロセスを経て，非鉄精錬プロセスの原料に戻 す技術：いわゆる山元還元技術が研究開発され, 既に実用 化している。

また，溶融処理物中の鉄や銅などの金属類は溶融メタル となる。溶融メタルは含有成分や比重の条件により，銅精 錬の原料や重機用カウンターウエイト材料として有効利用 されている。

\section{2 セメント固化}

セメントと混練することにより，ケイ酸カルシウムなど が水と水和反応により結晶硬化する。硬化には一週間程度 の養生期間を必要とする。有害物質はセメントのアルカリ 性により難溶性化合物となり固化物中で安定化する。

セメント固化処理装置は飛灰・セメントの供給設備と給 水装置と固化処理を行う混練機，成型機，造粒機，および セメント固化物の養生コンベアなどから構成される。

\section{3 薬剂処理}

飛灰に薬剤キレート剤と水を混練することで，重金属類 はキレート剤とキレート結合で強固に反応しキレート化合 物となる。処理物は固化物となり, 重金属は安定化して不 溶化する。

飛灰の薬剤処理装置は，飛灰・重金属安定剤（キレート 剤など)・水・pH 調整剤などの供給設備と, 固化処理を 行う混練機, 成型機, 造粒機, および処理物の搬送コンベ アなどから構成される。

セメント固化と薬剤処理に用いられる混練機は土木機械 として利用されている混合機械の応用である。攪拌式，パ ドル式，振動式などがあり，構造の一例を図 1 に示す。

また, 薬剤処理は焼却灰の重金属の安定化にも用いられ, 焼却炉の扊搬出装置である湿式灰押し出し装置や水中コン ベア式灰出し装置に薬剤を添加して処理する。この方法で 焼却灰と飛灰を一括処理することもある。

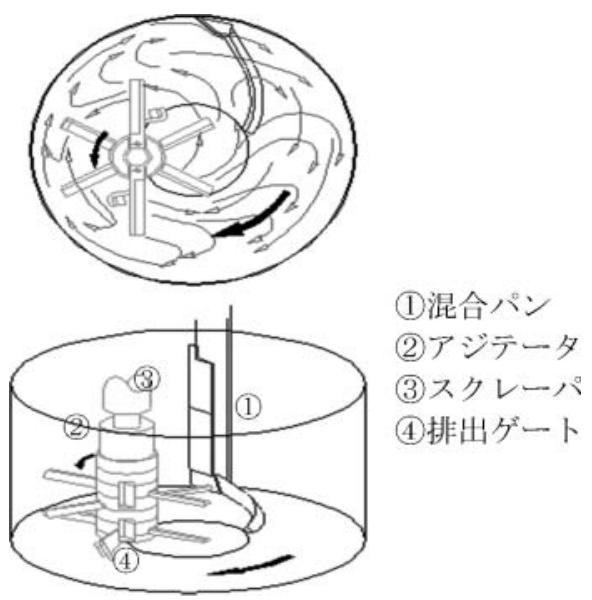

図 1 混合機の構造例（アイリッヒミキサー） 


\section{4 酸その他の溶媒による重金属抽出}

飛灰に水を加えスラリー状にして重金属を酸抽出し，抽 出液から抽出物質を硫化物や水酸化物またはキレート固化 物などにして除去する方法である。また，ばいじんを燒却 炬の排ガスを吹き込む水槽に入れ，重金属をガス中の $\mathrm{CO}_{2}$ ガスにより炭酸塩にして不溶化し脱水除去する方法（排ガ ス中和法）もこの方式に類する。

重金属抽出設備は，溶解槽・反応槽・凝集槽などの処理 水槽と, 飛灰・抽出溶媒・凝集沈殿薬剂などの供給設備, 凝集回収物の脱水装置，および処理物の搬送コンベアなど から構成される。

\section{5 ダイオキシン類無害化技術}

排ガスのダイオキシン類を高効率で除去した結果として, 集じん灰中にダイオキシン類が残る。この飛灰中ダイオキ シン類を無害化する必要がある。

溶融や焼成ほど高温を必要としない処理方法として，加 熱分解处理と揮発脱離处理がある。どちらも处理後の飛灰 を重金属安定化処理するのが一般的である。

加熱分解処理では加熱装置で $450^{\circ} \mathrm{C}$ 以上に加熱し，脱塩 素化反応させダイオキシン類を分解する。処理後の飛灰が ダイオキシン類を再合成しないように冷却装置で急令する。 図 2-1 に構造例を示す。

揮発脱離装置は，加熱装置で加熱すると同時に，温風を 吹き込々分解した有機化合物などを後段の触媒反応塔に送 り完全に酸化分解する。処理後の飛灰はダイオキシン類の 再合成が起こらないため冷却は不要である。図 2-2 に構造 例を示す。

\section{4. 利用技術}

\section{1 溶融処理}

溶融処理設備は，灰溶融炉とガス化溶融炉，ガス化改質 炬に分類される。表 3 に溶融処理設備の分類を示す。

灰処理用の灰溶融炉は，ごみ焼却施設で発電した電力を 用いる電気溶融方式と，施設に燃料を持ち込みその燃燒熱 で溶融する燃料溶融方式に大別することができる。電気炉 の加熱原理や，燃焼火炎等の加熱原理や構造によってさら に種別される。

一方，ガス化溶融炉は，ごみを乾燥・熱分解するガス化 炉と，チャーなどを含む残渣を燃焼さらには溶融する溶融 炉が分離型となっているのものと一体型になっているもの に大別される。さらにはごみの可燃成分を熱分解ガス化後 に熱エネルギーとして回収する方式と, 熱分解ガスのガス 改質を行って燃料ガスを得る方式に大別される。これらも， ガス化炉の炬構造によって，シャフト炉，キルン炉，流動 床炉などに分類される。

\section{2 代表的な溶融炉}

\subsection{1 電気式溶融炉の一例}

図 3-1〜図 3-3に，代表的な電気式溶融炉の構造例を示 す。

溶融炉本体，電極および電極昇降設備と電源設備，灰供 給設備，スラグ・メタル排出設備，排ガス燃焼設備および 排ガス処理設備などから構成される。

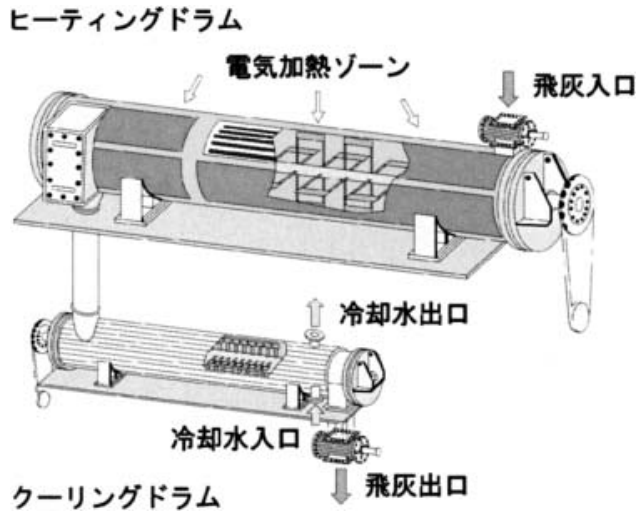

図 2-1 横型ドラム加熱装置(ハーゲンマイヤー式)

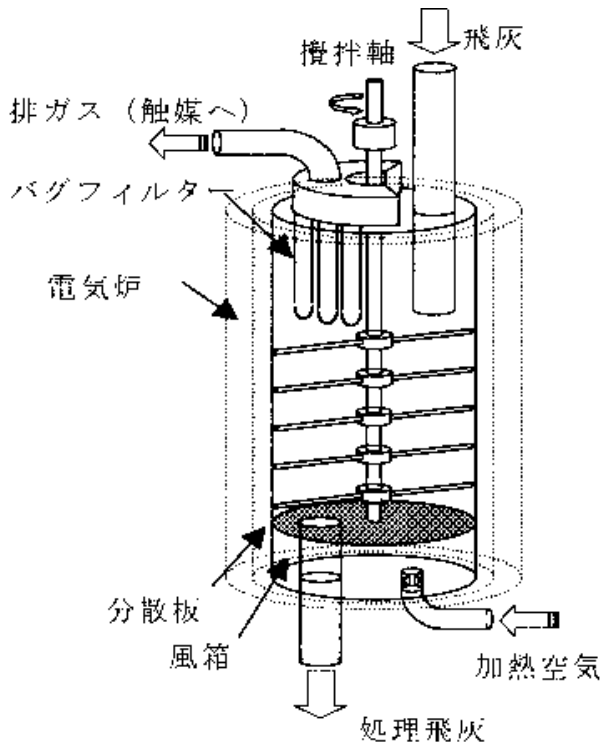

図 2-2 摚拌流動層加熱器式揮発脱離装置

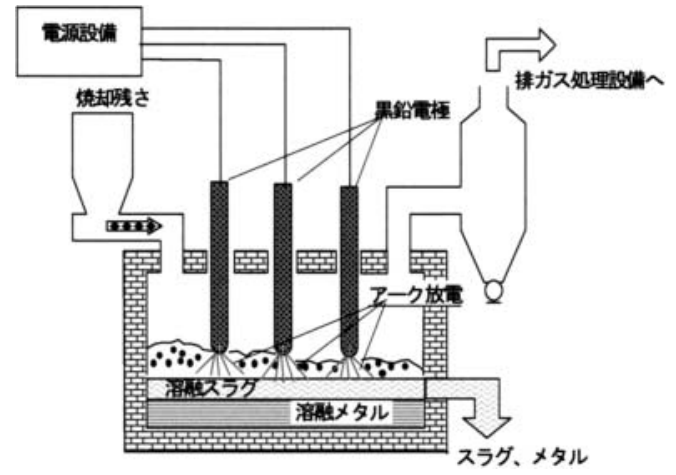

図 3-1 電気式灰溶融炬の構造例（アーク炉式） 

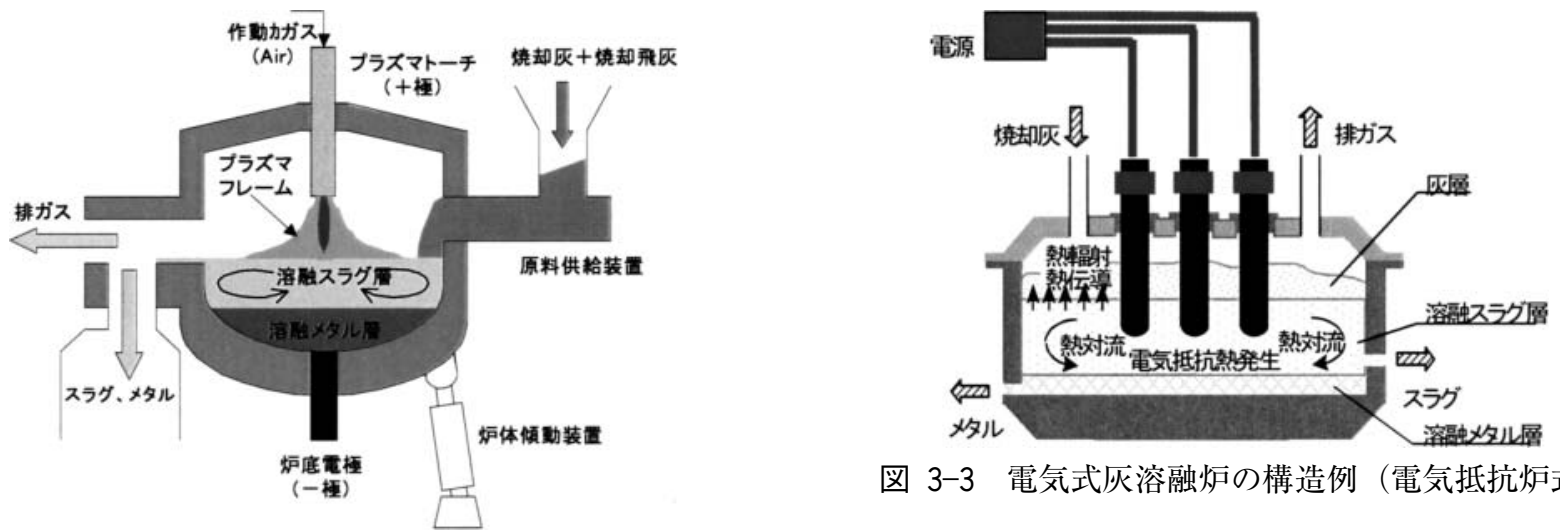

図 3-3 電気式灰溶融炉の構造例（電気抵抗炉式）

図 3-2 電気式灰溶融炬の構造例（プラズマ炉式）

表 3 溶融処理設備の分類（扊溶融炬とごみ直接溶融炉）

\begin{tabular}{l|l|l}
\hline \multirow{5}{*}{ 交流アーク式 } \\
\cline { 3 - 3 } & \multirow{5}{*}{ 直流電気抵抗式溶融炉 } \\
(電極正極, 電極㓌極 $)$
\end{tabular}




\subsection{2 燃料式溶融炉の一例}

図 4-1〜図 4-2に，代表的な燃料式溶融炉の構造例を示 す。溶融炉本体，バーナ等の燃焼設備，灰供給設備，スラ グ・メタル排出設備, 排ガス燃焼設備および排ガス処理設 備などから構成される。

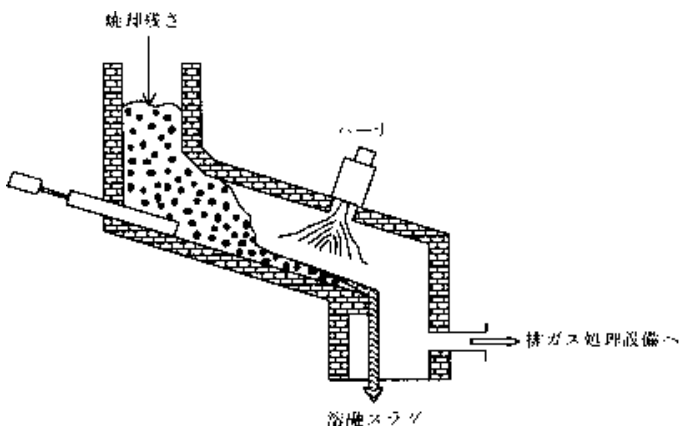

図 4-1 燃料式灰溶融炉の構造例（反射式表面溶融炉）

\subsection{3 ガス化溶融炉の一例}

図 5-1〜図 5-3に，代表的なガス化溶融炉の構造例を示 す。熱分解炉や溶融炉本体，ごみ供給設備，スラグ・メ夕 ル排出設備，熱分解ガス燃焼設備および排ガス処理設備な どから構成される。

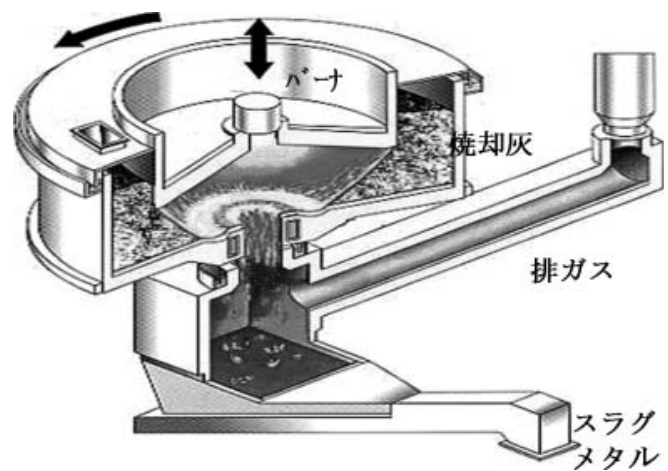

図 4-2 燃料式灰溶融炉の構造例（回転表面溶融炉）

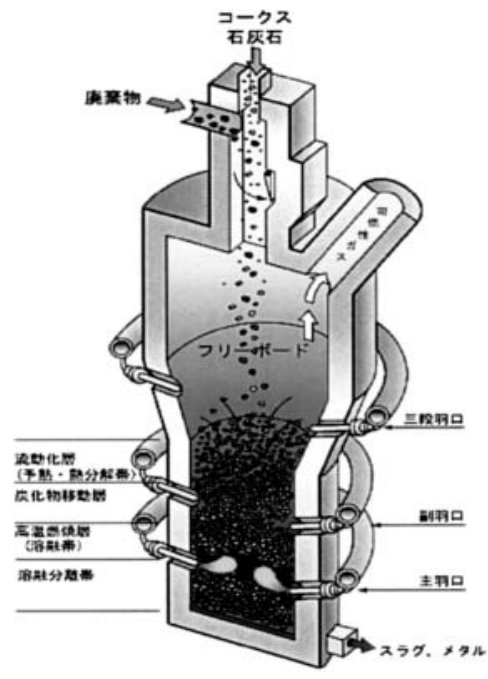

図 5-1 ガス化溶融炉の構造例（シャフト炉）

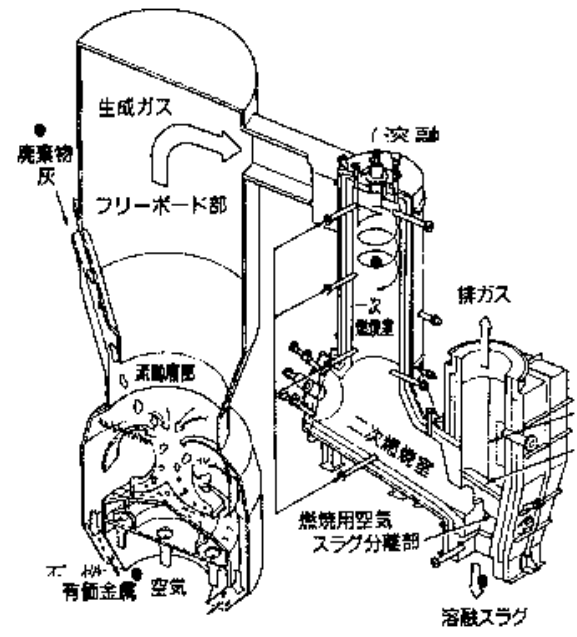

図 5-2 ガス化溶融炉の構造例（流動床）

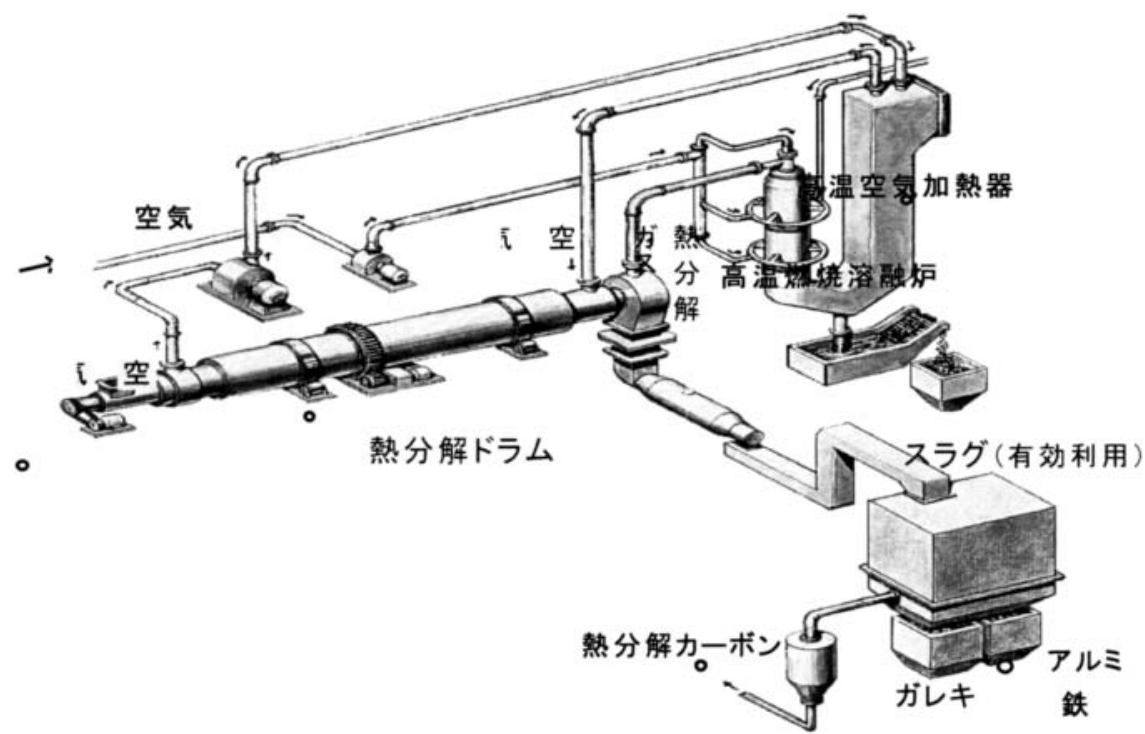

図 5-3 ガス化溶融炉の構造例（ロータリーキルン炉式溶融炉） 


\section{3 溶融スラグの冷却}

溶融スラグの冷却固化方法には, 水で急冷する水砕方式 と，空冷方式で代表される徐冷方式があり，冷却された金 属面で急冷・固化する間接水冷や, さらには, 冷却速度を 制御して結晶化する方式などがある。

\subsection{1 水砕スラグ}

水砕方式は，溶融スラグを冷却水槽に直接落下させ，急 冷・固化，細粒化して製造する。また，溶融スラグを噴射 水で急冷固化，細粒化後，冷却水槽に落下させ，製造する 場合もある。溶融スラグと溶融メタルを一緒に水砕するこ とができる。

砂状のスラグが得られる。針状スラグの除去や，微細ク ラックによる強度低下（スラグのかたさ）を改善するため, 利用に際しては破砕機などで軽破砕・摩砕処理を行う。

オーバーフロー式などでスラグとメタルを一緒に水砕す る場合には，金属鉄による錆びの発生防止やスラグ密度の 変動を防止するために, メタルの磁選処理を行う。

水砕設備はスラグ出滓部, 水砕部（水槽, 水噴射装置, 吹製樋など), 水砕水給排水ポンプ系, 水砕水冷却塔, ブ ロー水・排水処理装置, スラグコンベア, および水砕蒸気 換気装置から構成される。

\subsection{2 徐冷スラグ}

徐冷スラグには空気放冷する空冷式と間接水冷式，さら に冷却速度を制御する結晶化がある。

1) 空冷・結晶化

その代表である空冷スラグは，溶融スラグをモールドな どに受け，空気中で放冷しながら冷却搬送コンベアで搬出

して製造する。

空冷スラグは粒子形状が大きい塊状のスラグとして得ら れ, 利用目的に応じて破砕・粒度調整する。設備はスラグ 出滓部，スラグ注入部（樋など），モールド搬送コンベア， および放熱換気装置から構成される。

結晶化スラグは，溶融スラグを一定量モールドなどに受 け，保温室を経由しながら冷却速度を制御して搬送コンベ アで搬出して製造する。

結晶化するため強度が高いスラグとなって, 空冷と同様 に粒子形状が大きい塊状のスラグとして得られ，利用目的 に応じて破砕・粒度調整する。設備はスラグ出涬部, スラ
グ注入部（樋など），モールド部，搬送コンベア，保温室， および放熱換気装置から構成される。

2) 間 接水冷

間接水冷スラグは，冷却された金属面にスラグを注ぎ， 間接的に冷却して急冷凝固させ方法である。その後，凝固 したスラグを冷却搬送コンベア上で空冷して製造する。一 般的には冷却金属面の装置保護のため，メタルを含まない スラグの冷却に用いる。

間接水冷スラグは薄板状スラグとして得られ，利用目的 に応じて破砕・粒度調整する。

間接水冷設備はスラグ出滓部，スラグ注入部（樋など）, 間接冷却装置，搬送コンベア，および冷却媒体の冷却装置 から構成される。一般に冷却媒体は水を用いるが，水砕の ような水の污染が起こらないため排水処理設備は不要であ る。

\section{4 スラグ加工}

冷却後のスラグを有効利用するためスラグ加工処理，粒 度調整処理を行う。

\subsection{1 破砕・磨砕}

溶融スラグの種類や破砕目的に応じて破砕機や磨砕機が 選定される。溶融スラグの破砕装置の代表機種を表 4 に示 す。

(1) 水砕スラグに含まれる針状スラグを破砕する。

(2) 磁選の前処理として空冷または徐冷スラグを破砕す る

（3）空冷または徐冷スラグを用途に応じた粒度に破砕す る。

(4) 破砕時に発生する偏平なスラグや鋭角なスラグを整 形する。

\subsection{2 磁力選別}

溶融スラグと溶融メタルを一緒に排出する方式では，溶 融スラグに金属鉄が含まれる場合がある。特に，アスファ ルト混合物・路盤材などの道路用骨材やコンクリート骨材 などに使用する場合は，錆びの発生防止や密度変動の防止 のため金属鉄の除去が求められる。

磁力選別機には釣り下げ式とドラム式があるが，溶融ス ラグの磁選にはドラム式の実績が多い。磁選効果を高める ため，破砕前処理したり，定量供給機を設置したり，必要

表 4 溶融スラグの破砕機例

\begin{tabular}{|c|c|c|}
\hline 徐冷スラグ粗破砕 & 水砕スラグ粉砕・摩砕 & スラグ整形 \\
\hline $\begin{array}{c}\text { 圧縮破砕 } \\
\text { ジョー, } \\
\text { ロール, } \\
\text { コーン } \\
\text { 衝撃破砕 } \\
\text { ハンマー, } \\
\text { インペラー }\end{array}$ & $\begin{array}{l}\text { せん断破砕 } \\
\text { 回転（ロッド/ボール） } \\
\text { 振動（ロッド/ボール） } \\
\text { 圧縮破砕 } \\
\text { ロール } \\
\text { ロ衝撃破砕 } \\
\text { ディスク, ハンマー, インペラー } \\
\text { 摩砕 } \\
\text { 自制磨砕 }\end{array}$ & $\begin{array}{l}\text { 角取り機 } \\
\text { ドラム整形機 } \\
\text { パドル整形機 }\end{array}$ \\
\hline
\end{tabular}


に応じて多段にする。

\subsection{3 アルミ選別}

スラグに金属アルミニウムが含まれると，コンクリート 二次製品利用などでアルカリとの化学反応により水素発生 によって膨張や破戒が生じることがある。溶融炉形式によ りスラグに金属アルミニウムが含まれる場合には，渦電流 式アルミ選別機などを用いて除去する。

\section{4 .4 篩い分け}

スラグを道路用材料やコンクリート用骨材として利用す る場合には，利用材料に求められる粒度をに調整する必要 がある。上述の破砕・磨砕処理により所定の粒度を得られ ない場合には，篩い分け装置によりさらに粒度を調整する。

\section{5 スラグの資源化利用}

灰の溶融処理で生成する溶融スラグを有効利用する場合 には，利用目的に応じた物理的・化学的な品質特性が求め られると同時に，前述のばいじんなどの最終処分に適応さ れる溶出基準（表 2）よりもさらに高いレベルの環境安全 性が求められる。

\subsection{1 スラグの環境安全性}

溶融スラグの利用に当たっては，土壤污染，地下水污染 などの環境污染を引き起こす恐れのない安全な品質を有す ることが求められ，これまでは溶融固化物を有効利用する ための安全品質には，「一般廃棄物の溶融固化物の再生利 用に関する指針」(平成 10 年厚生省通達 生衛発第 508 号）の「一般廃棄物の溶融固化物に係わる目標基準」（表 5）が基本に考えられてきた。

表 5 一般廃棄物の溶融固化物に係 わる目標基準（溶出量規準）

\begin{tabular}{l|l}
\hline \multicolumn{1}{c|}{ 項 目 } & \multicolumn{1}{c}{ 溶出基準 } \\
\hline カドミウム & $0.01 \mathrm{mg} / 1$ 以下 \\
\hline 鉛 & $0.01 \mathrm{mg} / 1$ 以下 \\
\hline 六価クロム & $0.05 \mathrm{mg} / 1$ 以下 \\
\hline ひ素 & $0.01 \mathrm{mg} / 1$ 以下 \\
\hline 総水銀 & $0.0005 \mathrm{mg} / 1$ 以下 \\
\hline セレン & $0.01 \mathrm{mg} / 1$ 以下 \\
\hline
\end{tabular}

この規準は，溶融固化物の利用に関する内容を施工条件 として設計図書に明示して適正な利用を配慮することで, 市町村が自ら発注した公共建設工事において利用する際に 廃裹物の処分と見なさないとする判断基準である。この場 合の試験法は環境省告示 46 号の試験法で，基準值は土壤 の污染に係る環境基準と同レベルであり，目標規準を満た せば各種の用途に用いられた場合であっても十分安全と考 えられる。

\subsection{2 スラグの用途}

スラグを資源化する場合の用途は，以下のように一次製 品と二次製品や割業製品などの原料に分類できる。

1）一次製品（骨材）
スラグ利用の一次製品（骨材）としての用途として路盤 材 (路床材, 下層路盤材, 上層路盤材等), アスファルト 混合物用骨材，コンクリート骨材等が考えられる。

2) 二次製品

スラグ利用の二次製品としての用途としてコンクリート 二次製品用材料（歩道用ブロック，空洞ブロック，透水性 ブロック等) 等が考えられる。

3）割業製品などの原料

スラグをレンガやタイルなどの焼成品の原料やロックウ ール保温材の原料など，割業原料としての利用が考えられ る。以上のようなスラグを資源化する用途に応じて，強度， 耐久性，粒度等の品質規格を満足する必要がある。

\section{5 .3 溶融スラグの JIS 化}

溶融スラグに直接関連する規格として，コンクリート用 スラグ骨材と道路スラグとして規格化が平成 18 年 7 月 20 日に制定された（表 6）。

表 6 溶融スラグに直接関連する規格

\begin{tabular}{c|l|l}
\hline 1 & JIS A 5031 & $\begin{array}{l}\text { 一般廃棄物, 下水污泥又はそれらの焼 } \\
\text { 却灰を溶融固化したコンクリート用溶 } \\
\text { 融スラグ骨材 }\end{array}$ \\
\hline 2 & JIS A 5032 & $\begin{array}{l}\text { 一般廃棄物, 下水污泥又はそれらの焼 } \\
\text { 却灰を溶融固化した道路用溶融スラグ } \\
\text { 骨材 }\end{array}$ \\
\hline 3 & JIA K 0058 & スラグ類の化学物質試験方法 \\
\hline
\end{tabular}

なお，JIS A 5364 プレキャストコンクリート製品（H 16 年 3 月 20 日改正）には，溶融スラグ JIS 化以前の改正の ため TR A 0016 を満たす溶融スラグを利用した製品とし て規定されている。溶融スラグの骨材としての JIS 化が制 定されたことから，種々のコンクリート二次製品にも，今 後，JIS 適合の溶融スラグが含まれることが期待される。

\subsection{4 溶融スラグ JIS 化の内容}

1）安 全 性

制定された道路用とコンクリート用の溶融スラグ JIS の 中での安全品質の規定について述べる。溶出量と含有量に は, 生衛発第 508 号の目標規準の 6 項目に加え, ふっ素,

ほう素が試験項目として追加され，8項目となった。

2）有害物質の溶出量

原則は JIS K 0058-1５.項：かくはん試験（タンクーリ ーチング試験）により利用有姿試料（集荷有姿のスラグ単 体）で試験する。道路用スラグの場合は製造者と利用者の 協議により JIS K 0058-1 6. 項（環告 46 号試験）が可能 とされた。有害物質の溶出量の規準值を表 7 に示す。

3）有害物質の含有量

JIS K 0058-2による試験で集荷有姿のスラグ単体を粗砕 試料にて行う。（環告 19 号試験と同一）有害物質の溶出量 の規格值を表 8 に示す。

ただし，製造者が溶融スラグを他の材料や骨材と混合し たものにより規準を満足する（他のすべての品質規格も含 め満足する）場合は，それぞれの規格の適用ができる。こ 
表 7 溶出量基準（利用有姿試料：ス ラグで攪拌試験)

\begin{tabular}{l|r}
\hline \multicolumn{1}{c|}{ 項 目 } & \multicolumn{1}{c}{ 含有量基準 } \\
\hline 1. カドミウム & $0.01 \mathrm{mg} / 1$ 以下 \\
\hline 2. 鉛 & $0.01 \mathrm{mg} / 1$ 以下 \\
\hline 3. 六価クロム & $0.05 \mathrm{mg} / 1$ 以下 \\
\hline 4. ひ素 & $0.01 \mathrm{mg} / 1$ 以下 \\
\hline 5 . 総水銀 & $0.0005 \mathrm{mg} / 1$ 以下 \\
\hline 6. セレン & $0.01 \mathrm{mg} / 1$ 以下 \\
\hline 7 ふっっ素 & $0.8 \mathrm{mg} / 1$ 以下 \\
\hline 8. ほう素 & $1 \mathrm{mg} / 1$ 以下 \\
\hline
\end{tabular}

表 8 含有量基準（粗砕試料で環告 19 号試験)

\begin{tabular}{l|r}
\hline \multicolumn{1}{c|}{ 項 目 } & \multicolumn{1}{c}{ 含有量基準 } \\
\hline 1. カドミウム & $150 \mathrm{mg} / \mathrm{kg}$ 以下 \\
\hline 2. 鉛 & $150 \mathrm{mg} / \mathrm{kg}$ 以下 \\
\hline 3. 六価クロム & $250 \mathrm{mg} / \mathrm{kg}$ 以下 \\
\hline 4. ひ素 & $150 \mathrm{mg} / \mathrm{kg}$ 以下 \\
\hline 5. 総水銀 & $15 \mathrm{mg} / \mathrm{kg}$ 以下 \\
\hline 6. セレン & $150 \mathrm{mg} / \mathrm{kg}$ 以下 \\
\hline 7. ふっ素 & $4,000 \mathrm{mg} / \mathrm{kg}$ 以下 \\
\hline 8. ほう素 & $4,000 \mathrm{mg} / \mathrm{kg}$ 以下 \\
\hline
\end{tabular}

の場合，スラグ単体の含有量については，JIS 解説で含有 量基準值の 3 倍量を上限とするとされた。

その他の品質規格についての説明はここでは省略する (JIS を参照)。

\section{6 灰のセメント化設備（焼成処理・エコセメント）}

焼却残渣を粉砕，他の原料と混合造粒などの前処理を行 って，セメントの原料の一部としてセメント焼成炉に入れ て，加熱焼成することによりセメントクリンカーを作る方 法である。 $1,000^{\circ} \mathrm{C}$ 以上の状態で焼成することにより，重 金属類は排ガス側に移行しダストとして分離されるため, セメントクリンカーは無害化される。セメントクリンカー を粉砕してエコセメントを製造することが出来る。
セメント原料化は大規模なセメント製造設備で行うこと が多く，ごみ処理施設から灰を搬出して行うのが一般的で ある。飛灰をセメント原料化する場合は，飛灰中に含まれ る塩類を除去するため前処理として水洗処理する必要があ る。

なお，エコセメントの規格化は，2003 年に TR（技術標 準) から JIS に制定されている。

\section{7 溶融飛灰の山元還元}

溶融飛灰には溶融炉で揮散した低沸点の重金属を多く含 むため，非鉄精錬の原料化する試みが検討され実用化段階 にある。

例えば，平成 12〜14 年度に，金属鉱業事業団のナショ プロで溶融飛灰の山元還元の実証試験が行われた。水洗処 理後に配合造粒して溶鉱炉夕イプの鉱滓処理炉（MF炉） で処理し，粗酸化亜鉛などの精錬原料にする。このプロセ スは既に事業化している。

また，早稲田大学永田教授を中心とした溶融飛灰資源化 研究会が平成 15 年度に発足し, 産業界, 学会, 行政が参 画し, 社会システムとしての溶融飛灰処理システムを構築 するための検討を展開中である。

山元還元する場合の搬送手段は，精錬施設が限定した場 所であることから，遠距離輸送となる場合は JR や船舶等 によるコンテナ輸送方式, 近距離の場合はジェットパック 車方式など，輸送時の安全対策を考慮して立案計画する必 要がある。溶融飛灰を山元還元する場合には，搬送方式に 応じた溶融飛灰の搬出施設を設置する必要がある。

\section{8 塩類の再利用技術}

廃棄物処理で発生する塩類を再生利用する研究が，福岡 県リサイクル綜合研究センター花嶋センター長を会長, 福 岡大学樋口教授を副会長に「塩類再利用システム研究会」 としてスタートしている。

この研究会では, 以下の複製塩類をエコアルカリに再生 する構想である。

(1) 最終処分場における浸出水処理で生成する塩

(2) 焼却設備の排ガスの脱塩素処理した塩類

※エコアルカリとは, $\mathrm{KOH}, \mathrm{NaOH}$ の複合物で, 浸出水 脱塩処理由来の副生塩では $\mathrm{KCl}$ が多い。

\section{5. 終わりに}

一般廃棄物処理の分野においても，循環型社会を目指し た取り組みや安心安全を極めるための技術開発が進められ ており，本報では，焼却灰処理技術分野における関連技術 の一端を紹介した。分野の異なる事例であるが，関係各位 の一助になれば幸いである。 